\title{
Gowardia zebrina sp. nov., a new species in a little-known genus of arctic-alpine lichens (Parmeliaceae)
}

\author{
Trevor Goward ${ }^{1}$ \& Leena Myllys ${ }^{2}$
}

\section{Article info}

Received: 14 Jan. 2020

Revision received: 23 Apr. 2020

Accepted: 24 Apr. 2020

Published: 2 Jun. 2020

Associate Editor

Damien Ertz

\begin{abstract}
The fruticose lichen genus Gowardia (Parmeliaceae) was recently segregated from Alectoria based on phylogeny, morphology, secondary chemistry, ecology and distribution. As currently circumscribed, Gowardia comprises two wide-ranging species of arctic-alpine regions. Here we describe a third species, G. zebrina sp. nov., apparently endemic to subalpine regions in mountainous northwestern North America. Gowardia zebrina differs from other species in the genus by its combined subpendent habit, uniformly capillary branches, predominantly isotomic branching, pale-and-dark banding of the terminal branches, and epiphytic ecology. Morphological examination of North American herbarium specimens filed under A. nigricans suggests the existence of several additional undescribed species of Gowardia. A brief overview of morphological diversity in these species is given, shedding new light on the question of whether Gowardia should be subsumed under Alectoria, as some have suggested, or is more appropriately recognized as a distinct genus.
\end{abstract}

Key words: Alectoria, Alpine, British Columbia, Gowardia, lichen, taxonomy

\section{Introduction}

In 2009 the fruticose lichen genus Gowardia (Parmeliaceae, Lecanoromycetes) was segregated from Alectoria on the basis of morphology (pseudocyphellae plane versus raised, respectively), cortical chemistry (usnic acid versus alectorialic acid), habitat ecology (mostly epiphytic versus mostly terrestrial), distribution (mostly arctic-alpine versus mostly temperate-boreal) and phylogeny (Halonen et al. 2009; see also Miadlikowska et al. 2014 and Myllys et al. 2014). Only two species of Gowardia are currently accepted, both restricted to open, windswept habitats in arctic-alpine regions (Halonen et al. 2009). Gowardia arctica ranges across northern Canada and Russia (Halonen et al. 2009). Gowardia nigricans is more widespread, reported from arctic-alpine regions of both the Northern Hemisphere and Southern Hemisphere (Hawksworth 1972; Galloway 2007).

The recent discovery of a putative third species of Gowardia in the Coast Mountains of western Canada prompted a careful morphological review of material filed under Alectoria nigricans at the UBC herbarium in Vancouver, British Columbia. In this paper we have four objectives: (1) to formally describe our new species

\footnotetext{
${ }^{1}$ UBC Herbarium, Beaty Museum, University of British Columbia, Vancouver, BC V6T 1Z4, Canada; mailing address: Enlichened Consulting Ltd., 5369 Clearwater Valley Road, Upper Clearwater, BC V0E $1 \mathrm{~N} 1$, Canada

2 Botanical Museum, Finnish Museum of Natural History, P.O. Box 7, FI-00014 University of Helsinki, Finland

*Corresponding author e-mail: leena.myllys@helsinki.fi
}

as $G$. zebrina; (2) to update the genus phylogeny in support of this new species; (3) to provide an overview of morphological diversity in light of recent findings; and (4) to discuss the question, current in the literature, of whether Gowardia is more appropriately subsumed within Alectoria or treated as a genus in its own right.

\section{Materials and methods}

Our study has two parts: morphological, undertaken by the first author at UBC; and molecular, performed by the second author at $\mathrm{H}$. The morphological part involved a search for morphological characters potentially useful for species delimitation and was based on microscopic examination of nearly 150 specimens collected in arctic-alpine North America and filed under $G$. nigricans at UBC, Vancouver. While the main results of this study will be reported elsewhere (in prep.), our findings are nonetheless pertinent to the present paper, making it helpful to summarize our methods here.

Early in our study it became evident that many of the UBC specimens contained mixed collections of Gowardia, making it necessary to pre-sort prior to taxonomic evaluation. The contents of each packet were removed and lightly moistened with unchlorinated water. Once moist, the material was teased apart, sorted into distinct morphologies, arranged on sheets of blotting paper, and lightly pressed until dry. The resulting specimens, each now each now presumably taxonomically uniform, 
were then spot-tested for the presence of alectorialic acid - a secondary substance diagnostic for Gowardia against Alectoria (Halonen et al. 2009) - and finally, as necessary, transferred to new herbarium packets and re-curated. Each specimen was then examined under a dissecting microscope, with careful attention given to repeating morphological discontinuities.

The remainder of this study was undertaken at $\mathrm{H}$, where the second author examined recently collected specimens of Gowardia under a dissecting microscope and tested for secondary compounds with thin-layer chromatography (TLC) using solvents A and B (Orange et al. 2001). Subsequent phylogenetic study was based on sequences of nuclear ribosomal ITS regions from 29 specimens (Table 1), including four specimens from the genus Alectoria and 24 specimens from Gowardia. Bryocaulon divergens belongs to the Alectorioid clade sensu Divakar et al. (2015) together with Alectoria and Gowardia, and was used as outgroup. DNA extraction, amplification and sequencing were performed using the methods described in Myllys et al. (2011). The PCR products were cleaned and sequenced by Macrogen Inc. (www.macrogen.com).
The resulting contig sequences of each specimen were assembled using BioEdit v. 7.0.5.3 (Hall 1999). Voucher specimens were deposited in H and UBC.

Seven new ITS sequences were generated for this study. The remaining sequence data were obtained from the NCBI GenBank (www.ncbi.nlm.nih.gov/genbank/), including all available ITS sequences of Gowardia. The ITS sequences were aligned with MUSCLE v.3.8.31 (Edgar 2004) using EMBL-EBI's freely available web service (http://www.ebi.ac.uk/Tools/msa/muscle/). The ITS alignment is available online from the Dryad Digital Repository: https://doi.org/10.5061/dryad.51c59zw58. Phylogenetic relationships were inferred using maximum likelihood (ML) as optimality criteria. The ML analysis was performed in RAxML v.8.1.15 (Stamatakis 2104) located at CSC - IT center for Science (http://www.csc. fi/english). We divided the data set into three partitions (ITS1 region, 5,8S gene, ITS2 region) and used a GTRGAMMA model because GTR is the only substitution model implemented in RAxML. Nodal support was estimated with 1000 bootstrap replicates using the rapid bootstrap algorithm.

Table 1. Specimens used in molecular phylogeny, with GenBank accession numbers. Sequences generated in this study are bolded. The name G. nigricans is given in quotes, owing to current nomenclatural uncertainty concerning its application.

\begin{tabular}{|c|c|c|c|}
\hline Taxon & Locality & Voucher specimen, sequence ID & GenBank accession number \\
\hline Alectoria imshaugii & Canada, British Columbia & Goward 05-32 (UBC), H131 & EU282496 \\
\hline Alectoria ochroleuca & Russia, Murmansk Region & Uotila 49194 (H), L519 & KJ947934 \\
\hline Alectoria sarmentosa & Finland, Oulun Pohjanmaa & Halonen s.n. (OULU), H29 & EU282494 \\
\hline Alectoria sarmentosa & Canada, British Columbia & Goward 05-38 (UBC), H132 & EU282495 \\
\hline Bryocaulon divergens & USA, Alaska & Talbot \& Myers UNI062-34 (H), L475 & KJ947935 \\
\hline Gowardia arctica & Canada, Nunavut & Mattsson 5115 (UPS), L171 & EU282504 \\
\hline Gowardia arctica & Canada, NWT & Mattsson 5255 (UPS, H), L170 & EU282502 \\
\hline Gowardia arctica & Russia, Nenetsia & Pajunen s.n. (OULU), S146 & EU282503 \\
\hline Gowardia arctica & Canada, Nunavut & Mattsson 5142 (UPS), L169 & EU282505 \\
\hline Gowardia 'nigricans' & Finland, Enontekiön Lappi & Virtanen s.n. (OULU), S201 & EU282501 \\
\hline Gowardia 'nigricans' & Finland, Inarin Lappi & Hyvärinen s.n. (OULU), H79 & EU282499 \\
\hline Gowardia 'nigricans' & Finland, Enontekiön Lappi & Rämä s.n. S203 (OULU) & MT365233 \\
\hline Gowardia 'nigricans' & Norway, Troms & Timdal s.n. (O) & MK812557 \\
\hline Gowardia 'nigricans' & Norway, Buskerud & Rui \& Timdal s.n. (O) & MK812358 \\
\hline Gowardia 'nigricans' & Norway, Buskerud & Rui \& Timdal s.n. (O) & MK812235 \\
\hline Gowardia 'nigricans' & Norway, Finnmark & Westberg s.n. (O) & KY266967 \\
\hline Gowardia 'nigricans' & Norway, Finnmark & Timdal s.n. (O) & KY266922 \\
\hline Gowardia 'nigricans' & Norway, Finnmark & Holien s.n. (O) & KY266831 \\
\hline Gowardia 'nigricans' & Russia, Nenetsia & Kumpula, Strengell \& Moilanen s.n. (OULU), S202 & EU282500 \\
\hline Gowardia 'nigricans' & Sweden & Lundqvist 8377 (UPS) & DQ979996 \\
\hline Gowardia 'nigricans' & USA, Alaska & Talbot \& Myers \#UNI062-34A, L489 (H) & KR857115 \\
\hline Gowardia 'nigricans' & Canada, Quebec & McMullin TL013-B02 (CANL) & KU496936 \\
\hline Gowardia 'nigricans' & Chile & MAF-Lich. 18297 (MAF) & KU647289 \\
\hline Gowardia zebrina & Canada, British Columbia & Goward 96-485, L319 (H, UBC) & MT365234 \\
\hline Gowardia zebrina & Canada, British Columbia & Goward 96-485A, L320 (UBC) & MT365235 \\
\hline Gowardia sp. & Canada, NWT & Björk 24404, L373 (UBC) & MT365237 \\
\hline Gowardia sp. & Canada, NWT & Björk 28956, L617 (UBC) & MT365238 \\
\hline Gowardia sp. & Canada, British Columbia & Goward 06-1624, S187 (UBC) & MT365236 \\
\hline Gowardia sp. & USA, Alaska & Berg 3099, L838 (UBC) & MT365239 \\
\hline
\end{tabular}




\section{Results}

\section{Taxonomic diversity}

An important finding of our study is that Gowardia is likely a much more speciose genus than currently recognized: far from encompassing only two species worldwide, more than a dozen Gowardia species appear to be present in North America alone. Six of these putative new species are illustrated in Figures 1 and 2, while a seventh, the highly distinctive $G$. zebrina, is described below; see also Figure 4. This last species aside, formal description of most putative North American species must proceed

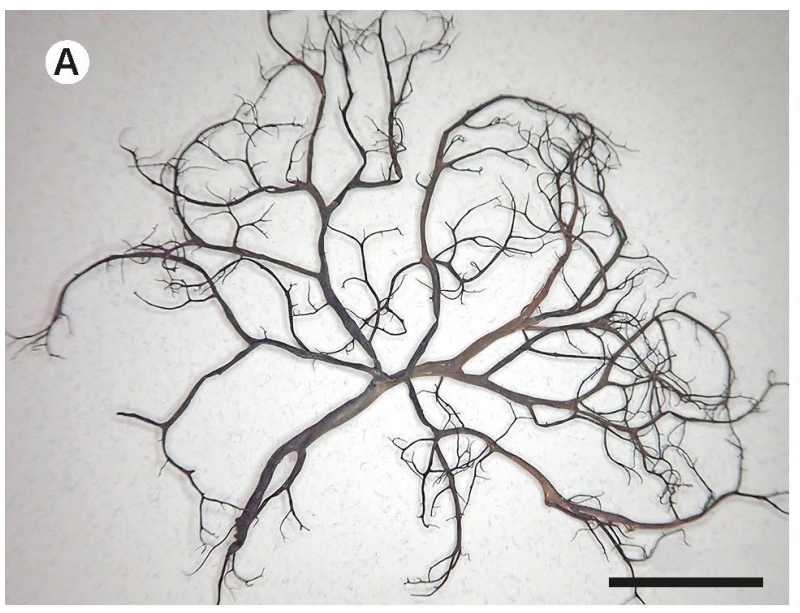

B
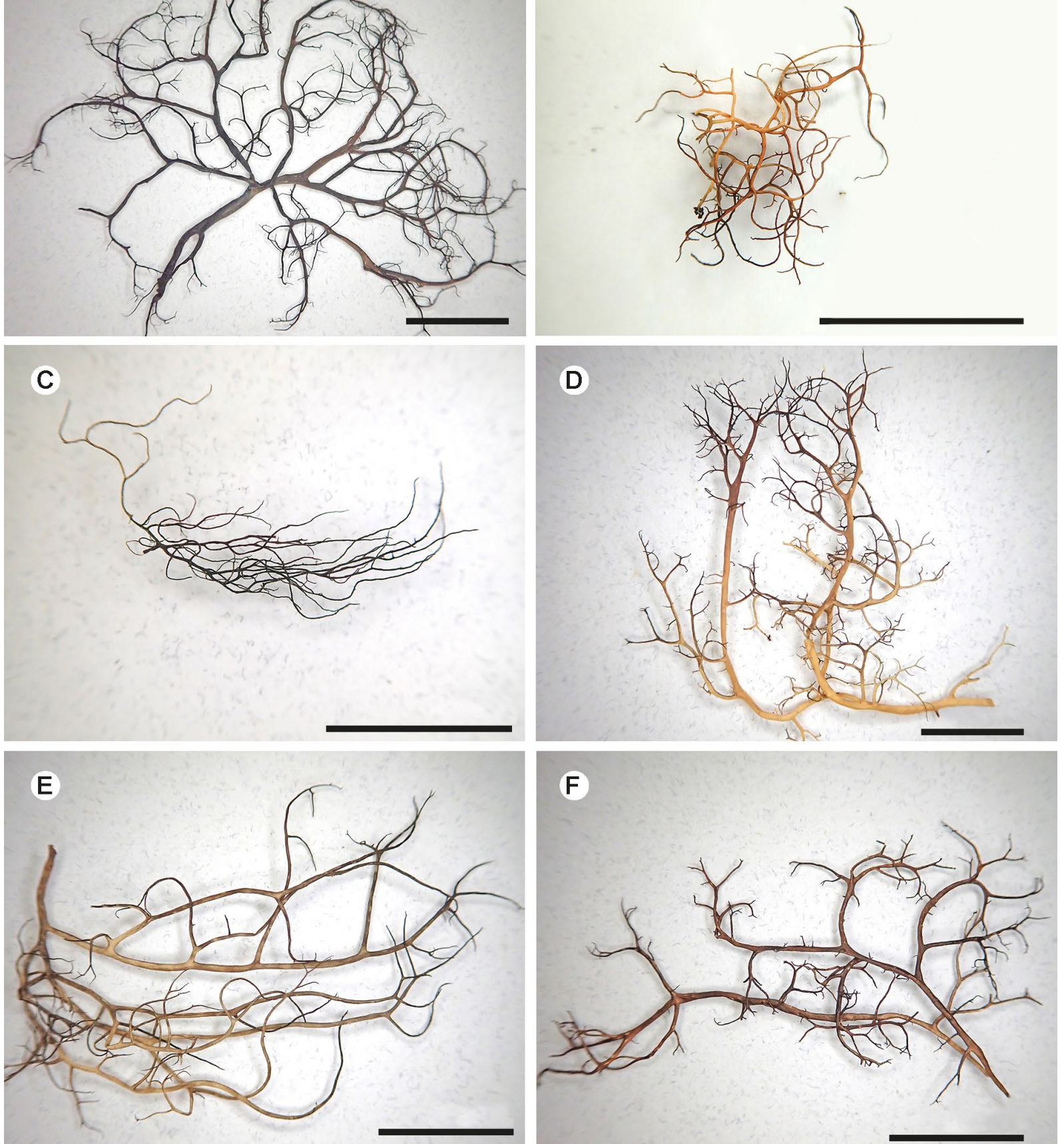

Figure 1. Morphological diversity. Examination of nearly 150 specimens of Gowardia at UBC suggests that this genus is much more speciose than hitherto recognized. Illustrated here is a small sampling of putative unnamed species present in North America. A - morph 'applanata' is decumbent and has flattened and/or foveolate branches that soon become black. Widespread in arctic-alpine habitats. (Otto 5425, UBC); B - morph 'salmonescens' is small and tufted and turns bright orange with long storage, at least in part. Apparently restricted to alpine elevations in the western cordillera. (Goward 78-773b, UBC); C - morph 'crinalis' is subpendent and has black capillary branches which tend to be friable when dry. Apparently restricted to subalpine habitats in the western cordillera. (Goward 06-1626, UBC); D - morph 'crocea' is upright and two-toned, usually orangish below and brownish to blackish above. Widespread both at arctic latitudes and southward at alpine elevations in the western cordillera. (Barrett s.n., L15477, UBC); E - morph 'elegans' combines decumbent stems with upright branches and has smooth, apically shiny branches that characteristically become whitish toward the base. Known only from the Aleutian Islands. (Talbot CAR001-X-18b, UBC); F - morph 'vitreusa' is blackish and shiny like G. arctica, but has glassy, brittle, somewhat angular branches that often bear minute longitudinal striations. Widespread across the North American arctic. (Barrett 36, UBC). Scales: A-F $=10 \mathrm{~mm}$. 


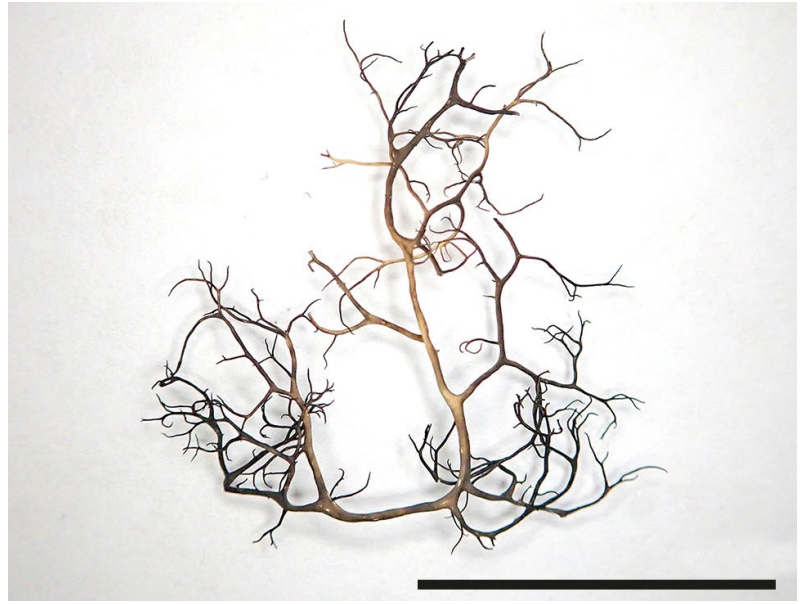

Figure 2. A small thallus of Gowardia morph 'applanata' (Otto 5360b, UBC). The pale narrow branches in the middle portion of this specimen are termed 'bone stems'; see text. Scale bar $=10 \mathrm{~mm}$.

with caution: first, owing to difficulties of taxonomic delimitation in a genus having few quantifiable characters, as noted below; and second, owing to the existence, in synonymy, of several published names of uncertain application (Hawksworth 1972; Brodo \& Hawksworth 1977; in prep.).

\section{Morphological notes}

In most regards, thallus morphology in Gowardia is broadly similar to that of other 'hair lichen' genera, permitting direct adoption of the standard descriptive terminology (e.g., Brodo \& Hawksworth 1977). On the other hand, it also differs markedly, for example in lacking diagnostic features such as apothecia, soralia, and chemical markers. Quantitative characters are thus few in this genus, and mostly limited to stem length (base to tip), internode length, pseudocyphellae length and cortical thickness. This makes Gowardia a taxonomically difficult genus in which species delimitation (in the absence of fresh material suitable for molecular testing) rests primarily on subtle qualitative details.

Still, our search for repeating morphological discontinuities did yield several characters presumed to be taxonomically informative. Of these, the most important are habit (upright, decumbent, mixed), branching (main stems conspicuous, inconspicuous, absent), branch profile (terete, subterete, flattened), surface hue (white, pale yellow, orangish, orangish brown, rust-brown, medium brown, purplish brown, dark brown, black), surface detail (even, weakly foveolate, strongly foveolate), luster (shiny, distinctly matte) and pliancy (pliant, distinctly brittle). Also taxonomically important are various features of the pseudocyphellae, including outline (fissural, hypheniform, narrowly fusiform, broadly fusiform, oval), elevation (immersed, plane, raised) and apical detail (blunt, short-tapered, long-tapered). In a few species the abundance of short pseudocyphellar spinules (absent, sparse, frequent, abundant) appears to be diagnostic, as does the presence/absence of vegetative nodular swellings, interfusing stems and branches, grooved

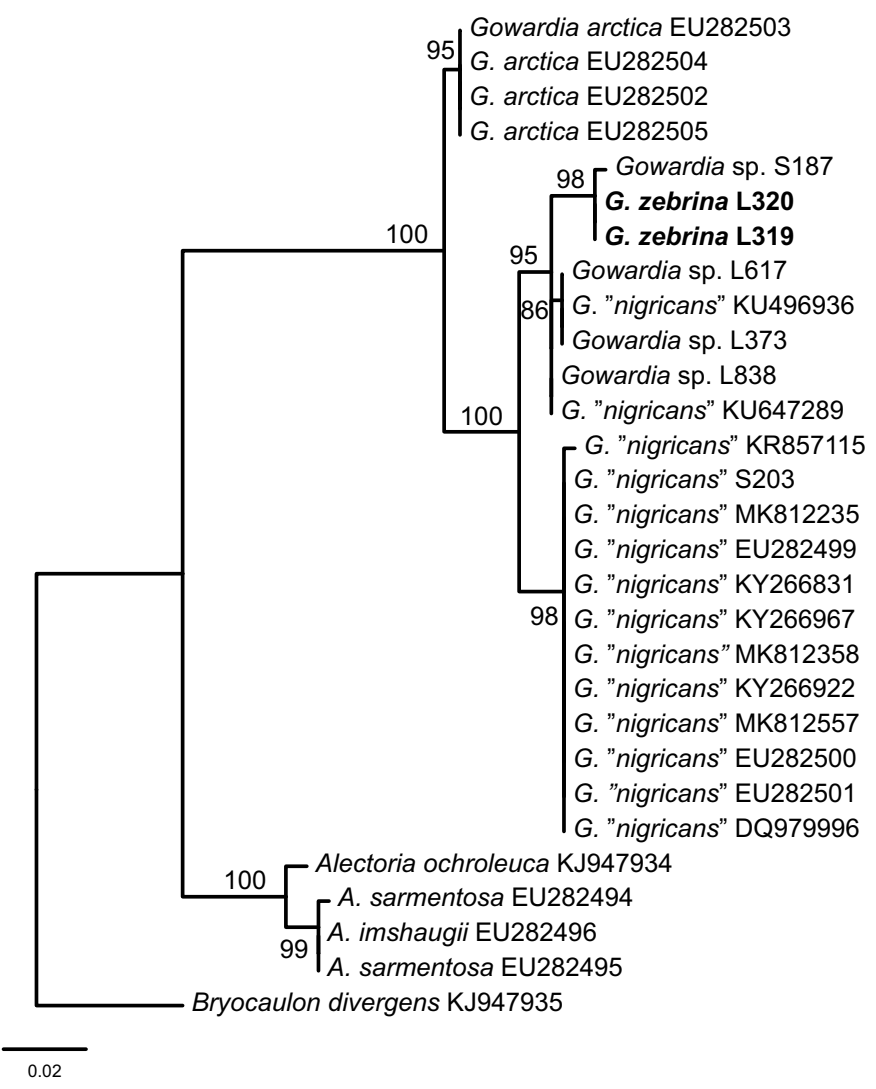

Figure 3. Phylogenetic position of Gowardia zebrina. A maximum likelihood phylogram obtained from RAxML analysis based on ITS data. Nomenclatural studies initiated as part of this study reveal the existence of previously published 'Alectoria' (= Gowardia) species of uncertain application, and at the same time call into question the taxonomic identity of G. nigricans. In light of these findings, we refrain from accepting earlier applications of that name, pending further study (in prep.). 
(sulcate) basal stems and pale-and-dark banding of the terminal branches (as in G. zebrina, below).

One additional character apparently informative for species delimitation in Gowardia is the presence/absence/ position of localized whitish or at any rate anomalously pale cortical patches. Such patches are often associated with distinct narrowings of the stems/branches and are here referred to as 'bone stems.' Bone stems appear to be unique to Gowardia and may perhaps be compared to the 'black emorient patches' recently reported in some species of Bryoria (Myllys et al. 2016). With the notable exception of $G$. zebrina (see below), this feature appears to be ubiquitous in Gowardia, occurring at any rate in all putative species known to us. In some cases, bone stems are confined to the basal portions of the thallus (where they may become copiously branched), while in others they regularly extend into the middle (Fig. 2) or even terminal portions. In later development they may either darken - in which case they become difficult to distinguish from regular stems - or else broaden into conspicuous, often flattened widenings of the supporting branch. While bone stems usually remain flexible in all stages of development, they become distinctly brittle in at least one of our putative species, hence presumably assisting in fragmentation and dispersal.

\section{Molecular phylogeny}

The ITS data set consisted of 487 characters, 45 of which were parsimony-informative. In the ML phylogeny (Fig. 3) both Gowardia and Alectoria are recovered as strongly monophyletic (100\%), a result consistent with earlier multigene phylogenies of Miadlikowska et al. (2014) and Myllys et al. (2014). Within Gowardia, two sequences form a strongly supported terminal group (98\%) and represent our new species G. zebrina. One sequence (S187) obtained from a specimen collected from intermontane $\mathrm{BC}$ groups with G. zebrina, but the specimen in question differs morphologically, for example, in the presence of bone stems. In addition, several other specimens are shown to be basal to G. zebrina, including two from the Canadian NWT, one from Alaska, and two G. 'nigricans' specimens from GenBank. The remaining G. 'nigricans' specimens form a separate strongly supported group. Note that the specimens identified as G. 'nigricans' are in need of further work before their taxonomic identity can be resolved (see caption to Fig. 3). Comparison of ITS sequences revealed rather high sequence similarity between G. 'nigricans' and G. zebrina, (98\%), but in the phylogeny these species are clearly separate. Gowardia 'nigricans' and G. zebrina also differ in their morphology and distribution (in prep.).

\section{Taxonomy}

Gowardia zebrina Goward \& Myllys, sp. nov.

(Fig. 4A-B)

\section{MycoBank MB 835591}

Diagnosis: Thallus fruticose, subpendent, to $6-8(-10) \mathrm{cm}$ in length, without conspicuous main stems, branches capillary, pale creamy yellow (becoming pale orange in herbarium) except blackening where exposed, superficially resembling Alectoria sarmentosa but more delicate and without conspicuously bulging pseudocyphellae, terminal branches repeatedly pale-and-dark banded, usnic acid absent. On trunks and lower branches of conifers at subalpine elevations.

Type: Canada, British Columbia, Vancouver Island, Mt. Cain, $10 \mathrm{~km}$ NW of Schoen Lake, $1.5 \mathrm{~km}$ NNW of Mt. Cain alpine park society lodge. Open herb meadow with scattered Tsuga mertensiana. On lower branches of Tsuga. $50^{\circ} 15^{\prime} \mathrm{N}, 126^{\circ} 21^{\prime} \mathrm{W}$, alt. 1440 m, 14 Sept. 1996 T. Goward 96-485 (UBC - holotype, BG, CANL, H, HBG, KUN, S, TRH, TUR, UPS - isotypes). GenBank ITS: MT365234.

Description. Thallus up to $7-12(-15) \mathrm{cm}$ in diameter, often with persistent basal points of attachment, also sometimes becoming attached at branch tips; branches capillary, up to $6-8 \mathrm{~cm}$ long from base to tip, internodes mostly to $2-4 \mathrm{~cm}$ long, terminal branches mostly long and flexuous, often repeatedly banded with pale and dark patches, otherwise pale creamy yellow except brownish or blackish where exposed, becoming pale orange in herbarium, mostly tough and pliant, matte to weakly shiny, of uniform width, $0.2-0.3 \mathrm{~mm}$ diam., except to $0.5 \mathrm{~mm}$ diam. toward base; medulla well developed, generally filling branch interior. Branching predominantly isotomic
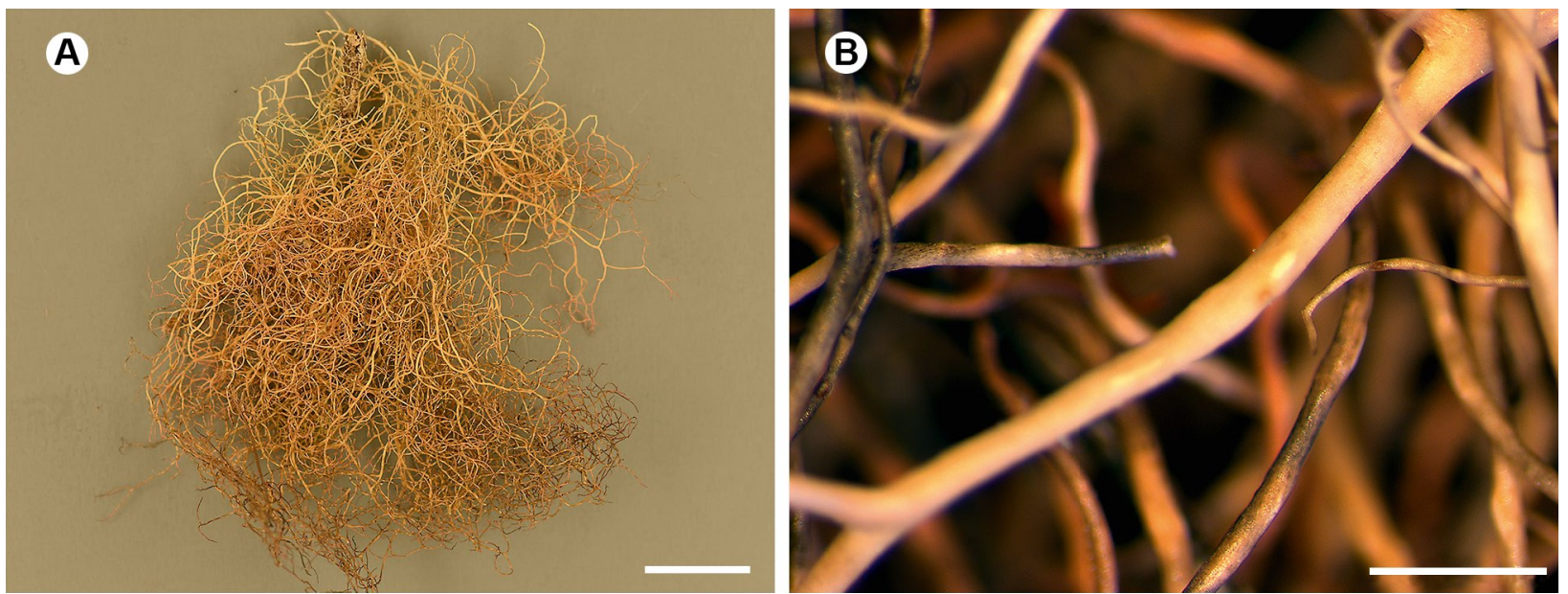

Figure 4. Gowardia zebrina (holotype). A - showing habit; B - showing detail of branches with pseudocyphellae and pale-and-dark banding. Scales: $\mathrm{A}=10 \mathrm{~mm} ; \mathrm{B}=1 \mathrm{~mm}$. 
dichotomous, or at any rate subbasal portions without distinct main stems, angles between branches variable; pseudocyphellar spinules generally absent. Soralia and isidia absent, except (stress-induced) 'explosion soralia' rarely present in basal portions. Pseudocyphellae sparse to abundant, \pm inconspicuous, $0.1-0.5(-1.0) \mathrm{mm}$ long, whitish, fissural to more often narrowly fusiform, occasionally in part hypheniform and/or oval, terminal portions blunt or at most short-tapering, plane or weakly emergent, becoming \pm impressed in age, mostly single, but occasionally in part laterally paired, rarely in threes.

Apothecia rare, lateral, supporting branches often geniculate; apothecial rim concolorous with thallus; disc to $0.8-2 \mathrm{~mm}$ wide, reddish brown, initially concave but soon plane or becoming convex in age; asci few-spored; spores ellipsoid, 19-25 × 8-11 um, simple, thick-walled, colourless when young, becoming brownish at maturity.

Conidiomata frequent, generally sparse, brown to blackish, shiny, to $0.05 \mathrm{~mm}$ diam., conidiogenous cells not seen.

Chemistry. Cortex and medulla $\mathrm{K}+$ pale yellow (filter paper), $\mathrm{C}+$ pink (fleeting) or apparently $\mathrm{C}-, \mathrm{KC}+$ red (fleeting), $\mathrm{PD}+$ yellow. Containing alectorialic acid, unknown substances: A: 2-3, 3/B: 3, 5 brownish yellow.

Etymology. Zebrina calls attention to the pale-and-dark banding of the terminal branches, most clearly seen in pale specimens sheltered from high light.

Distribution and habitat. Gowardia zebrina appears to be narrowly endemic to coastal northwest North America, where it is currently known from the Insular Mountains of southern Vancouver Island $\left(50^{\circ} \mathrm{N}\right)$, northward along the Coastal Mountains to the vicinity of Hazelton $\left(55^{\circ} \mathrm{N}\right)$. Here it grows at subalpine elevations on the trunks and lower branches of conifers, especially Abies and Tsuga, in open old-growth forests subject to wind-scouring of the winter snow. To be sought in adjacent portions of southeast Alaska.

Comments. Gowardia zebrina is apparently a rare species currently known from only two localities. On the other hand, the possibility should not be overlooked that it has simply been undercollected owing, for example, to its subalpine distribution and superficial resemblance to Alectoria sarmentosa. The pale-and-dark banding characteristic of the terminal branches is diagnostic. Actually, G. zebrina is most likely to be confused with alectorialic-containing members of the hair lichen genus Bryoria, especially B. nadvornikiana (sensu Velmala et al. 2014) and $B$. pikei. Neither of these species occurs at subalpine elevations, however, and both in any case contain barbatolic acid and lack the pale-and-dark banding of the terminal branches. Within its habitat, G. zebrina grows in proximity to Alectoria sarmentosa, readily distinguished by the latter's coarser branching, yellowish green hue (usnic acid) and distinctly bulging pseudocyphellae.

Additional material seen. CANADA. British Columbia, Vancouver Island, Mt. Cain, $10 \mathrm{~km} \mathrm{NW}$ of Schoen Lake, $1.5 \mathrm{~km}$
NNW of Mt. Cain alpine park society lodge. On trunk of Tsuga mertensiana. $50^{\circ} 15^{\prime} \mathrm{N}, 126^{\circ} 21^{\prime} \mathrm{W}$, alt. $1440 \mathrm{~m}, 14$ Sept. 1996 T. Goward 96-485A, 96-493 (UBC) - topotypes; Nass River Drainage, Hazelton area, Nine Mile Mountain. Alpine area with small firs in protected sites. On Abies. $55^{\circ} 19^{\prime} \mathrm{N}, 127^{\circ} 30^{\prime} \mathrm{W}$, alt 5200’, 8 Aug. 1970. K. E. Ohlsson 2986 (UBC L226).

\section{Discussion}

Lichen classification has undergone much scrutiny in recent years, as a constant flow of molecular findings both uphold and challenge traditional taxonomic concepts grounded in morphology, secondary chemistry, spore characters, etc. (Lumbsch \& Leavitt 2011; but see also Spribille et al. 2016). At the genus level this has led to debate over the appropriate circumscription of several macrolichen clades, including Gowardia.

Lumbsch \& Huhndorf (2010) were the first to suggest that Gowardia should be subsumed within Alectoria, owing to 'the possibility of errors due to the analysis performed.' This suggestion was later taken up by Crespo et al. (2016) and Divakar et al. (2017), notwithstanding the prior publication of analyses showing a strongly supported sister group relationship for Gowardia and Alectoria (Miadlikowska et al. 2014; Myllys et al. 2014). In such a case, the decision on whether to recognize one genus or two is preferably made on the basis of integrated phenotypic discontinuity (Lücking 2019).

In the event, usage over the past decade has clearly supported recognition of Gowardia as a distinct genus. Not only was Gowardia taken up in the latest Ascomycetes Classification (Lücking et al. 2017 ['2016']), it has also been adopted in virtually all recent floristic and vegetational studies within its range: e.g., Piercey-Normore (2010), Hansen (2012), Koroleva (2014), McMullin \& Dorin (2016), Wang et al. (2017), Moseev \& Sergienko (2018).

Notwithstanding this wide acceptance, the recent introduction of temporal banding into lichenology (Kraichak et al. 2017; Divakar et al. 2017) has once again called the generic status of Gowardia into question (Thell et al. 2018). Temporal banding is the practice of linking taxonomic rank to pre-determined cut-off dates on time-calibrated phylotrees, with a view to creating stable, 'objective' classification systems ultimately grounded in quantitative data (Hennig 1966). In the temporal banding system promoted by Divakar et al. (2017), the minimum cut-off date for genus recognition is set at 29.5 to 32.5 million years ago - too early to support separate genus status for Gowardia and Alectoria. In this analysis, the younger genus name Gowardia should be subsumed within Alectoria.

Yet it is fair to say that the strict application of temporal banding in lichenology has so far received little support (but see McCune et al. 2018). In an extended rebuttal entitled 'Stop the abuse of time! Strict temporal banding is not the future of rank-based classification in fungi (including lichens) and other organisms', Robert Lücking (2019) shows that the mechanical application of temporal banding can too often result in significant loss 
of morphogical, chemical, distributional and evolutionary information, without any compensating benefit.

Certainly this is the case with Gowardia, whose optional reduction to synonymy under Alectoria obscures several unifying features of substrate ecology, distribution, secondary chemistry and thallus morphology (see, e.g., Table 2 in Halonen et al. 2009), not least being the presence of bone stems, a feature unique to the genus. Crucially, all seven putative Gowardia species illustrated in Figures 1 and 2 are morphologically much closer to Bryoria (e.g., section Divaricatae; Myllys et al. 2011) than to Alectoria. 'Age,' notes Lücking (2019), 'is just one trait of clades, but it cannot be the only one to determine rank.'

\section{Acknowledgements}

We dedicate this study to Emmanuël Serusiaux, lichénologue extraordinaire, on the occasion of his retirement. We thank Ms. Laura Häkkinen for help with laboratory work. We are grateful to Saara Velmala and Leena Helynranta for preparing the photographs and figures. Mikhail Zhurbenko, Sergey Chesnokov and Liudmila Konoreva are thanked for arranging material of G. arctica deposited in LE at our disposal. Steve Leavitt and Curtis Björk are gratefully acknowledged for helpful discussions. The study was financially supported by the Academy of Finland (grant 1133858).

\section{References}

Brodo, I. M. \& Hawksworth, D. H. 1977. Alectoria and allied genera in North America. Opera Botanica 42: 1-164.

Crespo, A., Divakar, P. K., Leavitt, S. D. \& Lumbsch, H. T. 2016. A synopsis of the generic classification of Parmeliaceae in Mexico in the light of molecular data. Bibliotheca Lichenologica 110: 55-67.

Divakar, P. K., Crespo, A., Wedin, M., Leavitt, S., Myllys, L., McCune, B., Randlane, T., Bjerke, J., Ohmura, Y., Schmitt, I., Boluda, C., Alors, D., Valiente, B. R., Del-Prado, R., Ruibal, C., Buaruang, K., Núñez-Zapata, J., Amo de Paz, G., Rico, V., Molina, M. C., Elix, J., Esslinger, T., Tronstad, I. K., Lindgren, H., Ertz, D., Gueidan, C., Saag, L., Tõrra, T., Singh, G., Dal Grande, F., Parnmen, S., Beck, A., Benatti, M., Blanchon, D., Candan, M., Clerc, P., Goward, T., Grube, M., Hodkinson, B., Hur, J. S., Kantvilas, G., Kirika, P., Lendemer, J., Mattsson, J. E., Messuti, M. I., Miadlikowska, J., Nelsen, M., Ohlson, J., Pérez-Ortega, S., Saag, A., Sipman, H., Sohrabi, M., Thell, A., Thor, G., Truong, C., Yahr, R., Upreti, D., Hawksworth, D., Cubas, P. \& Lumbsch, T. 2015. Evolution of complex symbiotic relationships in a morphologically derived family of lichen-forming fungi. New Phytologist 208: 1217-1226.

Divakar, P. K., Crespo, A., Kraichak, E., Leavitt, S. D., Singh, G., Schmitt, I. \& Lumbsch, H. T. 2017. Using a temporal method to harmonize family- and genus-level classification in the largest clade of lichen-forming fungi. Fungal Diversity 84: 101-117.

Edgar, R. C. 2004. MUSCLE: multiple sequence alignment with high accuracy and high throughput. Nucleic Acids Research 32: 1792-1797.

Galloway, D. J. 2007. Flora of New Zealand: Lichens, including lichen-forming and lichenicolous fungi, Vol 1. Manaaki Whenua Press, Lincoln, New Zealand.

Hall, T. A. 1999. BioEdit: a user-friendly biological seuene alignment editor and analysis program for Windows 95/98/NT. Nucleic Acids Symposium Series 41: 95-98.

Halonen, P., Myllys, L., Velmala, S. \& Hyvärinen, H. 2009. Gowardia (Parmeliaceae) - a new alectorioid lichen genus with two species. The Bryologist 112: 138-146.
Hansen, E. S. 2012. A contribution to the lichen flora of Melville Bugt north of Lat. $75^{\circ} \mathrm{N}$, north west Greenland. Botanica Lithuanica 18: $117-122$.

Hawksworth, D. H. 1972. Regional studies in Alectoria (Lichenes) II. The British species. Lichenologist 5: 181-261.

Hennig, W. 1966. Phylogenetic Systematics. University of Illinois Press, Chicago, IL.

Koroleva, N. 2014. Phytosociological evaluation of terrestrial habitat types in Pyramiden area (Svalbard, Norway). Czech Polar Reports 4: 193-211.

Kraichak, E., Crespo, A., Divakar, P. K., Leavitt, S. D. \& Lumbsch, H. T. 2017. A temporal banding approach for consistent taxonomic ranking above the species level. Scientific Reports 7: 2297.

Lumbsch, H. T. \& Huhndorf, S. 2010. Myconet Volume 14. Part one. Outline of the Ascomycota 2009. Fieldiana Life and Earth Sciences 1: $1-40$.

Lumbsch, H. T. \& Leavitt, S. D. 2011. Goodbye morphology? A paradigm shift in the delimitation of species in lichenized fungi. Fungal Diversity 50: 59-72.

Lücking, R. 2019. Stop the Abuse of Time! Strict Temporal Banding is not the Future of Rank-Based Classifications in Fungi (Including Lichens) and Other Organisms. Critical Reviews in Plant Sciences 38: 199-253.

Lücking, R., Hodkinson, B. P. \& Leavitt, S. D. 2017. [2016] The 2016 classification of lichenized fungi in the Ascomycota and Basidiomycota - Approaching one thousand genera. The Bryologist 119: $361-416$.

McCune, B., Arup, U., Breuss, O, Di Meglio, E., Di Meglio, J., Esslinger, T. L., Magain, N, Miadlikowska, J., Miller, A. E., Muggia, L. Nelson, P. R., Rosentreter, R., Schultz, M., Sheard, J. W., Tønsberg, T. \& Walton, J. 2018. Biodiversity and ecology of lichens of Katmai and Lake Clark National Parks and Preserves, Alaska. Mycosphere 9: 859-930.

McMullin, R. T. \& Dorin, B. C. 2016. The Chic-Choc Mountains are the last southern refuge for arctic lichens in eastern North America. Arctic Science 2: 183-193.

Miadlikowska, J., Kauff, F., Högnabba, F., Oliver, J. C., Molnár, K., Fraker, E., Gaya, E., Hafellner, J., Hofstetter, V., Gueidan, C., Otálora, M. A. G., Hodkinson, B., Kukwa, M., Lücking, R., Björk, C., Sipman, H. J. M., Burgaz, A. R., Thell, A., Passo, A., Myllys, L., Goward, T., Fernández-Brime, S., Hestmark, G., Lendemer, J., Lumbsch, H. T., Schmull, M., Schocj, C. L., Sérusiaux, E., Maddison, D. R., Arnold, A. E., Lutzoni, F. \& Stenroos, S. 2014. A multigene phylogenetic synthesis for the class Lecanoromycetes (Ascomycota): 1307 fungi representing 1139 infrageneric taxa, 317 genera and 66 families. Molecular Phylogenetics and Evolution 79: $132-168$.

Moseev, D. S. \& Sergienko, L. S. 2018. The composition and structure of plant communities in the southern part of the Franz Joseph Archipelago. Herald of the Kola Science Centre of the RAS (or Russian Academy of Sciences) 3: 14-24.

Myllys, L., Velmala, S., Holien, H., Halonen, P., Wang, L. S. \& Goward, T. 2011. Phylogeny of the genus Bryoria. Lichenologist 43: 617-638.

Myllys, L., Velmala, S., Lindgren, H., Glavich, D., Carlberg, T., Wang, L. S. \& Goward, T. 2014. Taxonomic delimitation of the genera Bryoria and Sulcaria, with a new combination Sulcaria spiralifera introduced. Lichenologist 46: 737-752.

Myllys, L., Velmala, S., Pino-Bodas, R. \& Goward, T. 2016. New species in Bryoria (Parmeliaceae, Lecanoromycetes) from north-west North America. Lichenologist 48: 355-365.

Orange, A., James, P. W. \& White, F. J. 2001. Microchemical methods for the identification of lichens. British Lichen Society.

Piercey-Normore, M. D. 2010. Lichens from the Hudson Bay Lowlands: northwestern interior treeline peatlands of Wapusk National Park in Manitoba. Botany 88: 923-929.

Stamatakis, A. 2014. RAxML version 8: a tool for phylogenetic analysis and post-analysis of large phylogenies. Bioinformatics 30 : 1312-1313. 
Spribille, T., Tuovinen, V., Resl, P., Vanderpool, D., Wolinski, H., Aime, M. C., Schneider, K., Stabentheiner, E., Toome-Heller, M., Thor, G., Mayrhofer, H., Johannesson, H. \& McCutcheon, J. P. 2016. Basidiomycete yeasts in the cortex of ascomycete macrolichens. Science 353: 488-492.

Thell, A., Kärnefelt, I. \& Seaward, M. R. D. 2018. Splitting or synonymizing - genus concept and taxonomy exemplified by the Parmeliaceae in the Nordic region. Graphis Scripta 30: 130-137.
Velmala, S., Myllys, L., Goward, T., Holien, H. \& Halonen, P. 2014. Taxonomy of Bryoria section Implexae (Parmeliaceae, Lecanorales) in North America and Europe, based on chemical, morphological and molecular data. Annales Botanici Fennici 51: 345-371.

Wang, L. S., Wang, X. Y., Liu, D., Myllys L., Shi, H. X., Zhang, Y. Y., Yang, M. X. \& Li, L. J. 2017. Four new species of Bryoria (Lichenized Ascomycota: Parmeliaceae) from the Hengduan Mountains, China. Phytotaxa 297: 29-41. 